\title{
Histological Description of Morphogenesis of the Gastroesophageal Mucosa of Gallus gallus domesticus (Linnaeus, 1758)
}

\author{
Descripción Histológica de la Morfogénesis de la Mucosa Gastroesofágica \\ de Gallus gallus domesticus (Linnaeus, 1758)
}

\begin{abstract}
Adriana Ventura*; Aparecida Alves do Nascimento**; Marcos Antônio José dos Santos**; Danielle Alcântara Vieira-Lopes*; Armando Sales ${ }^{* * *}$ \& Nadja Lima Pinheiro***
\end{abstract}

\begin{abstract}
VENTURA, A.; DO NASCIMENTO, A. A.; DOS SANTOS, M. A. J.; VIEIRA-LOPES, D. A.; SALES, A. \& PINHEIRO, N. L. Histological Description of Morphogenesis of the Gastroesophageal Mucosa of Gallus Gallus Domesticus (Linnaeus, 1758). Int. J. Morphol., 31(4):1331-1339, 2013.
\end{abstract}

SUMMARY: The ontogenesis of the gastroesophageal mucosa involves morphological alterations related to its structure and the function of each segment. The present study describes the histogenesis of the mucus-secreting epithelium and glands of the esophagus, gizzard, and proventriculus of the chicken (Gallus gallus), and identifies alterations in the secretion pattern of glycosaminoglycans (GAG's). We analyzed 38 chicken embryos, processed the material collected following the histological routine, and then stained it with hematoxylin-eosin for the analysis of tissue structure and with Gomori's trichrome for the identification of conjunctive tissue and collagen fibers. We used the PAS histochemical technique for the analysis of neutral GAG's and the AB pH 2.5 histochemical technique for the analysis of acid GAG's. The embryos at late stage of development had the esophagus wall composed of four layers: mucosa, submucosa, muscularis, and serosa, whereas the proventriculus and the gizzard were composed of three layers: mucosa, muscularis, and serosa. In all three segments, we identified the superficial epithelium as mucus-secreting; in the esophagus this epithelium was mucussecreting only at the initial development stages. The proventricular glands began to form at the initial development stages, whereas the tubular glands began to form in the gizzard just after the 15th day. The differences in the production of GAG's in these regions of the digestive tract are related to development stages, functions, and physiological requirements of each segment, and to the gradual adjustment of the body to the post-hatching life.

KEY WORDS: Chicken embryos; Development; Glycosaminoglycans; Esophagus; Stomach.

\section{INTRODUCTION}

The digestive tract (DT) of chicken embryos (Gallus gallus) begins to develop on the first day of incubation (Shin et al., 2005). At first it is represented by a simple and undifferentiated tube (Klasing, 1999; Smith et al., 2000). Between the third and the fourth day of embryo development, the stomach begins to differentiate into two morphologically distinct regions. On the sixth day, the proventriculus and the gizzard are already anatomically differentiated, acquiring histological characteristics specific of each organ (Fukuda \& Yasugi, 2005).

The esophageal mucosa of birds is characterized by being pleated and presenting mucous glands in the lamina propria (Banks, 1992). The stomach of birds is composed of two histologically and physiologically distinct regions, a glandular portion or proventriculus, and a muscular portion or gizzard (Takiguchi et al., 1988; Liman et al., 2010). In an anterior position, the proventriculus is responsible for peptic digestion. It is histologically characterized by being internally covered by mucus-secreting cylindrical cells and by containing several branched glands in the connective tissue, which are formed by oxyntic-peptic cells that secrete both hydrochloric acid and pepsinogen (Illanes et al., 2006; Askoy \& Cinar, 2009; Liman et al.). The gizzard is located posteriorly in the stomach. It is characterized by presenting a secretion plate on the inner surface and a well-developed muscle layer. Both characteristics represent an adaptation to grind grains (Catroxo et al., 1997; Askoy \& Cinar; Liman et al.).

* Postgraduate Program in Animal Biology, Universidade Federal Rural do Rio de Janeiro, Seropédica, RJ, Brazil.

** Institute of Biology, Area of Histology and Embryology, Departamento de Biologia Animal, Instituto de Biologia, Universidade Federal Rural do Rio de Janeiro (UFRRJ), Seropédica, RJ, Brazil.

*** Postgraduate Program, Institute of Biology, Universidade Federal Rural do Rio de Janeiro (UFRRJ), Seropédica, RJ, Brazil. 
The ontogenesis of the gastroesophageal mucosa involves morphological alterations, which differ in each segment of the DT, according to the structure and function of the organ. Hence, the goal of the present study was to describe the morphogenesis of the gastroesophageal mucosa of G. gallus and to identify alterations in the secretions produced by cells and glands during development. The chicken embryo is an excellent biological model, and has a fast, accessible and economically viable development (Leksrisompong et al., 2007; Xu et al., 2012).

\section{MATERIAL AND METHOD}

We collected 38 embryos of G. gallus (Leghorn breed) with 12 to 20 days of incubation, from Granja Tolomei, Rio de Janeiro, Brazil. The incubation was made in an automatic incubator at controlled temperature $\left(37.5^{\circ} \mathrm{C}\right)$ and humidity $(60 \%)$. The embryos were euthanized by hypothermia (at $4^{\circ} \mathrm{C}$ for $4 \mathrm{~h}$ ), following the Resolution 714 of 20/06/2002 of CRMV, process 23011792/2011-31, approved by the Research and Ethics Committee of UFRRJ. We classified the embryos in stages that followed Hamburger \& Hamilton (1992). Next, we dissected the embryos for the removal of the esophagus, proventriculus, and gizzard, fixed them in bouin solution for $8 \mathrm{~h}$, processed those using routine histological techniques, consisting of dehydration in increasing ethanol series (70 to $100 \%$ ), diaphanization in xylol, and embedment in histosecparaffin to obtain 3- $\mu \mathrm{m}$ histological sections and then stained it with hematoxylin-eosin (HE) for the analysis of tissue structure and with Gomori's trichrome for the identification of conjunctive tissue and collagen fibers. We used the Periodic Acid Schiff (PAS) histochemical technique for the analysis of neutral GAG's and the Alcian Blue pH 2.5 (AB) histochemical techniques for the analysis of acid GAG's, beyond checking the early secretory activity of tissues. We obtained photomicrographs with a Nikon Coolpix 100 digital camera, coupled with a Nikon Ellipse E100 microscope.

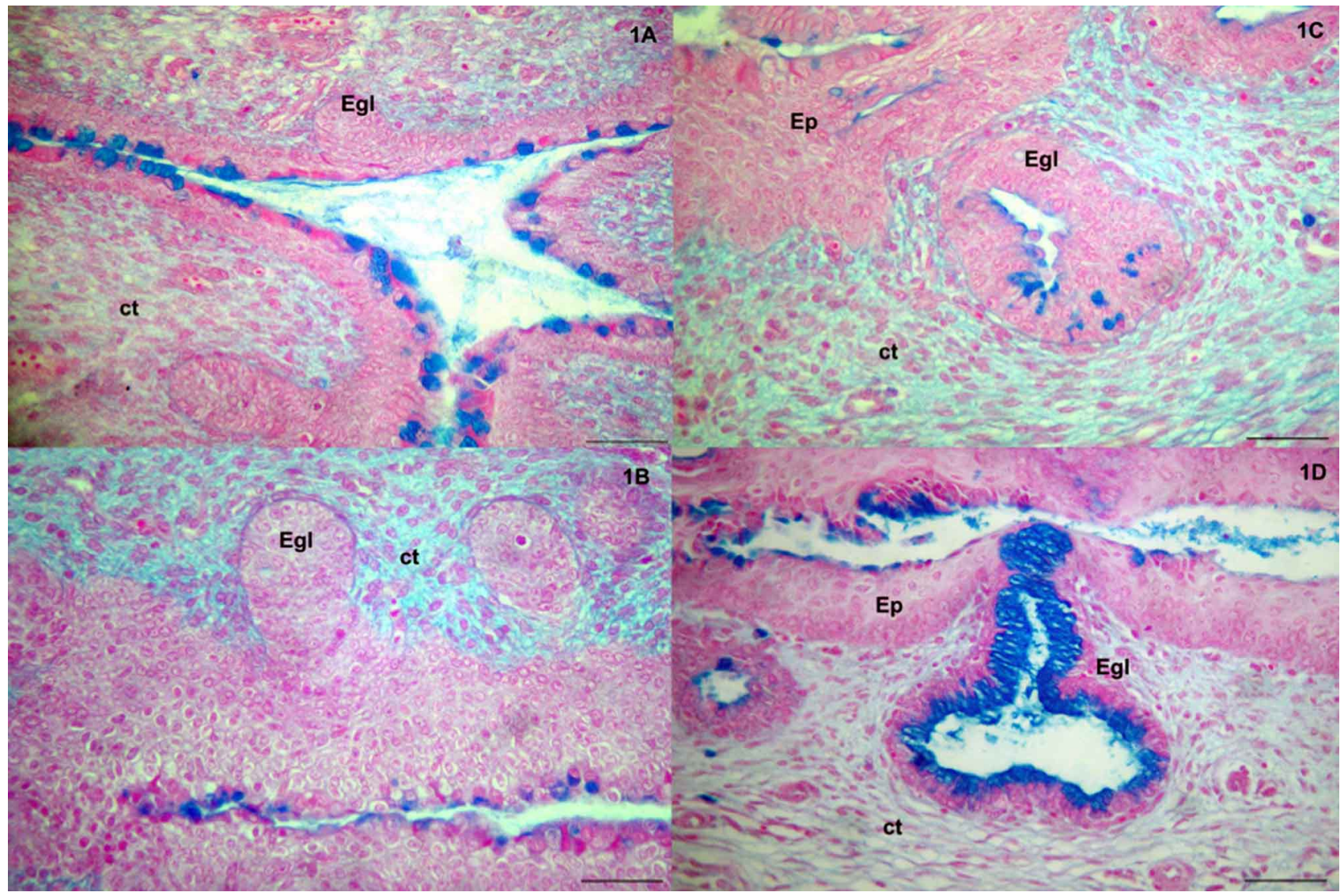

Fig. 1. Histochemical characteristics of esophagus at different development stages (AB). Embryos of 14 days (A) and 15 days (B) showed reactive cells on epithelium surface. Embryos from 16 (C) to 20 days (D) were reactive to Alcian Blue, staining stronger on epithelium surface and weaker primordial of gland, while embryos of 20 days (C) showed the opposite results. (Ep) Superficial epithelium;

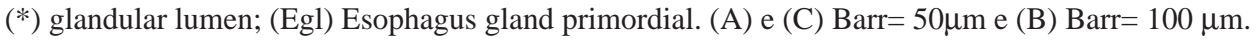


Esophagus. The esophagus wall of 12 to 20 -day-old embryos was composed of four layers: mucosa, submucosa, muscularis, and serosa. The mucosa was covered by nonkeratinized and secreting squamous stratified epithelium. The primordia of esophageal glands were already present on the 12th day of development (stage 37). We observed the

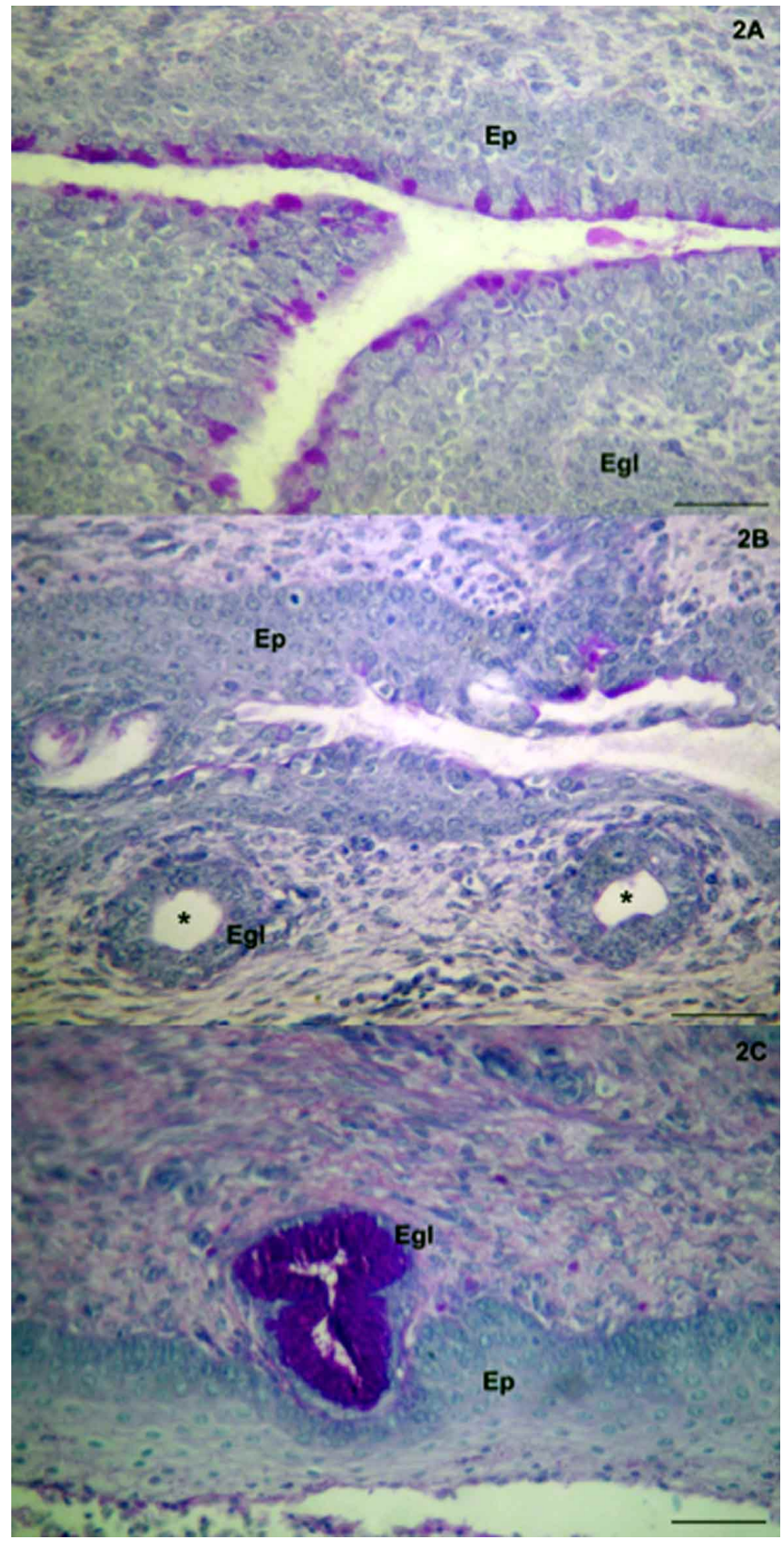

Fig. 2. Histochemical characteristics of esophagus at different development stages (PAS). Embryos of 14 days (A) and 17 days (B) showed reactive cells on epithelium surface. Embryos from 16 to 18 days were reactive to PAS, staining stronger on epithelium surface and weaker primordial of gland, while embryos of 20 days (C) showed the opposite results. (Ep) Superficial epithelium; (*) Glandular lumen; (Egl) Esophagus gland primordial. (A) e (C) Barr $=50 \mu \mathrm{m}$ e (B) Barr $=100 \mu \mathrm{m}$. development of glands from the budding of epithelial cells, which formed agglomerates on the connective tissue. These cells moved away gradually from the surface epithelium and deepened in the mesenchyme. At first, the primordia of esophageal glands were cells clusters arranged circularly, similar to the cells that compose the surface epithelium at the same stage (Fig. 1A and B; Fig. 2A). From the 16th day on (stage 41), the cells that formed the esophageal glands organized themselves in one or two layers around the lumen (Fig. 2B). Only on the 20th day (stage 44) the cells of the glands became characteristic of mucosa glands: tall, with nucleus located at the basal region, (Fig. 1C and D; Fig. 2 C). The cells of the epithelium of the mucosa were positive for the production of both types of glycosaminoglycans (GAG's), neutral and acid, from the 12th day to the 18th day (stages 37 to 43) (Fig. 2A and B), which indicates that in this stage the epithelium is secretory. The primordia of esophageal glands were negative to the techniques used in the present study until the 16th (stage 41), the glandular tissue of the primordia was weakly positive from the 17th to the 19th day and strongly positive on the 20th day (Fig. 1C and D; Fig. 2C), when it showed full production of neutral and acid GAG's (Table I). The macro and microscopic observations did not evidence the development of the ingluvies or crop from the stages 37 to 46; the esophageal tube opened directly in the glandular stomach.

\section{Stomach}

Proventriculus. The proventriculus of 12 to 20-day-old embryos (stages 37 to 45 ) was composed of three layers: mucosa, muscularis, and serosa. The proventriculus at 12 days of development was internally covered by pseudostratified cylindrical epithelium on mesenchymal connective tissue (Fig. 3A); the muscularis of the mucosa was not evident in all development stages observed in the present study, as confirmed with Gomori's trichrome (Fig. 3C). At this stage, the proventricular glands were formed by pseudostratified cylindrical epithelium, and some cells were binucleated. In longitudinal section, we observed a single layer of cells lining the inside of the duct, the future central excretory duct. The glands showed no branches and were formed by simple tubules (Fig. 3A, Fig. 4A, B and C). However, from the 13th day on (stage 39), the process of gland branching began; the epithelial layer formed invaginations toward the mesenchymal connective tissue and giving rise to the excretory duct and branches of the proventricular glands. From the 14th day on (stage 39), we observed cells with a cube-like shape, spherical nucleus, and acidophilic and granular cytoplasm.

On the 15th day (stages 40) we noticed that the branches of the proventricular glands were more prominent 
Table I. Histochemical reactions of GAG's in the esofagus of chick embryos.

\begin{tabular}{lcccc}
\hline \multirow{2}{*}{ Incubation of } & \multicolumn{3}{c}{ PAS } & \multicolumn{3}{c}{ AB 2.5 } \\
\cline { 2 - 5 } & Lining epithelium & Glands & Lining epithelium & Glands \\
\hline 12 & +++ & - & +++ & - \\
13 & +++ & - & +++ & - \\
14 & +++ & - & +++ & - \\
15 & ++ & + & ++ & - \\
16 & ++ & + & ++ & + \\
17 & + & ++ & ++ & + \\
18 & + & ++ & + & ++ \\
19 & + & +++ & + & ++ \\
20 & - & - & +++ \\
\hline
\end{tabular}

$(+++)$ Strong reaction, $(++)$ moderate reaction; $(+)$ weakly reaction, $(-)$ negative reaction, $(\sim)$ structure is not yet formed.

(Fig. 3B and C, Fig. 4D). At this development stage, the epithelium of the mucosa layer differentiated into a simple cylindrical epithelium with mucus-secreting cells (Fig. 3B), the folds became deeper and deeper, forming concentric grooves (Fig. 3C; Fig. 4D). From the 17th day of development on (stage 42), the proventriculus showed a morphology similar to an adult animal, but the muscularis of the mucosa was not evident.

The proventricular structures were positive for the PAS and AB histochemical techniques at all development stages. The surface epithelium was strongly positive, mainly at the most advanced stages, whereas the oxyntic-peptic cells were weakly positive for the production of both types of GAG's, neutral and acid, at all stages from 12 to 20 days (Table II).

Gizzard. The gizzard of 6 to 14-day-old embryos was composed of three layers: mucosa, musculary, and serosa. The mucosa layer was covered by pseudostratified cylindrical epithelium. At this stage there is no trace of the tubular gland (Fig. 5A; Fig. 6A, B and C). The cells of the mucosa layer reacted to the PAS and $\mathrm{AB}$ techniques; the histochemical results are presented in Table III. In 12-dayold embryos (stage 37), only the apical region of the epithelial

Fig. 3. Histological structure and characteristics of proventriculus at different development stages. Embryos of 12 days (A) showed pseudostratified epithelium in mucosa layer and from of gland. Since 16 days (B) the superficial epithelium become simple cylindric mucossecretor (HE). And the glands were covered with simple cubical epithelium, increase its ramifications. Muscularis of mucosa haven't been evidenced until 19th day (C) with Gomori Trichrome. (Ep) Superficial epithelium; (Ep*) Glandular epithelium; (ct) Mesenchymal connective tissue. (Pgl) Proventriculos gland primordium; (D) Excretory duct. (A) barr= $50 \mu \mathrm{m}$ e (B) e (C) Barr $=100 \mu \mathrm{m}$.

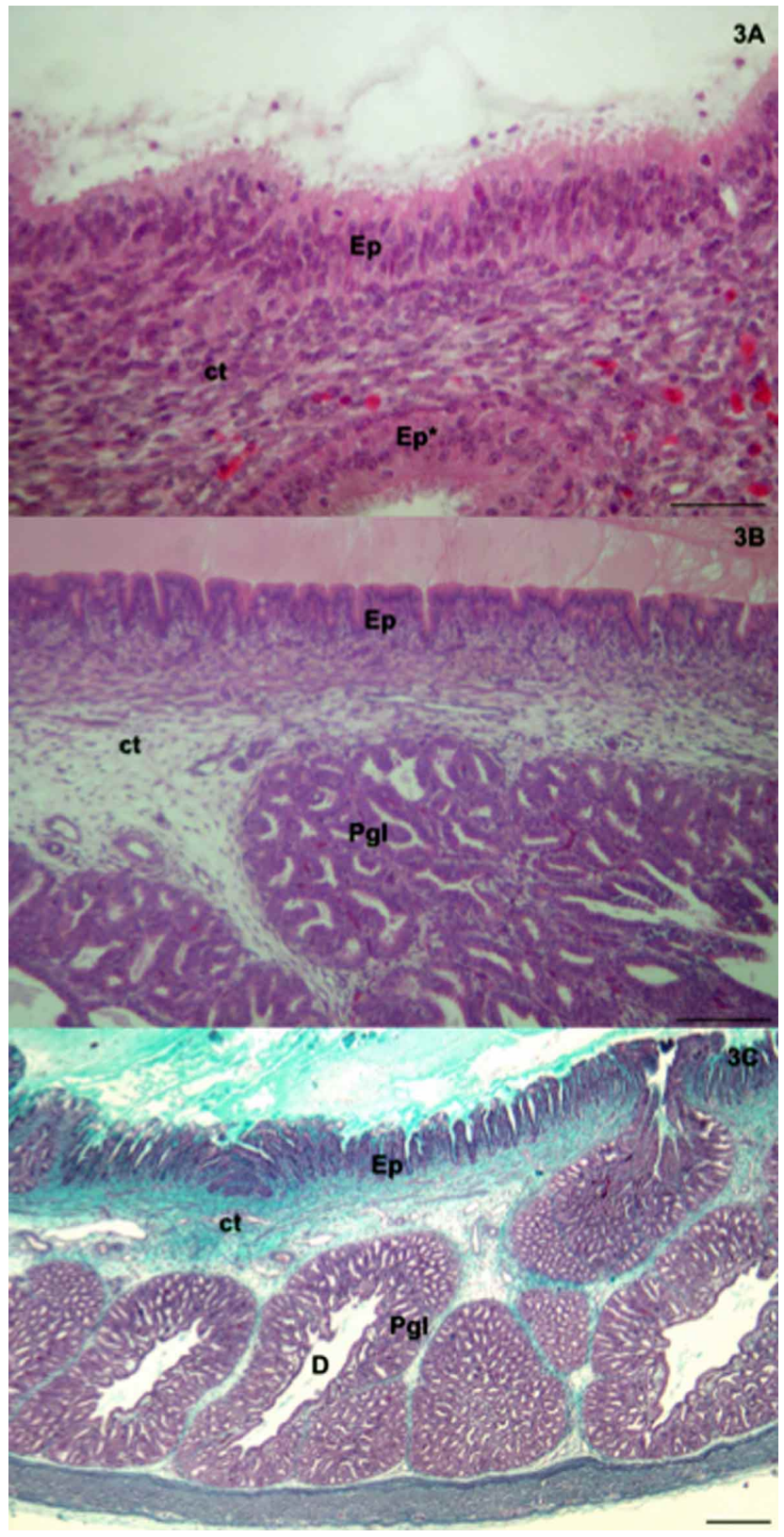


VENTURA, A.; DO NASCIMENTO, A. A.; DOS SANTOS, M. A. J.; VIEIRA-LOPES, D. A.; SALES, A. \& PINHEIRO, N. L. Histological Description of Morphogenesis of the Gastroesophageal Mucosa of Gallus Gallus Domesticus (Linnaeus, 1758). Int. J. Morphol., 31(4):1331-1339, 2013.

Table II. Histochemical reactions of GAG's in the proventriculus of chick embryos.

\begin{tabular}{lcccc}
\hline Days of & \multicolumn{2}{c}{ PAS } & & \multicolumn{2}{c}{ AB 2.5 } \\
Incubation & Lining epithelium & Glands ducts & Lining epithelium & Glands ducts \\
\hline 12 & ++ & + & ++ & + \\
13 & ++ & + & ++ & + \\
14 & ++ & + & ++ & + \\
15 & ++ & + & ++ & + \\
16 & +++ & + & +++ & + \\
17 & +++ & + & +++ & + \\
18 & +++ & + & +++ & + \\
19 & +++ & + & ++ & + \\
20 & +++ & ++ & + \\
\hline
\end{tabular}

$(+++)$ Strong reaction, $(++)$ moderate reaction; $(+)$ weakly reaction, $(-)$ negative reaction, $(\sim)$ structure is not yet formed.

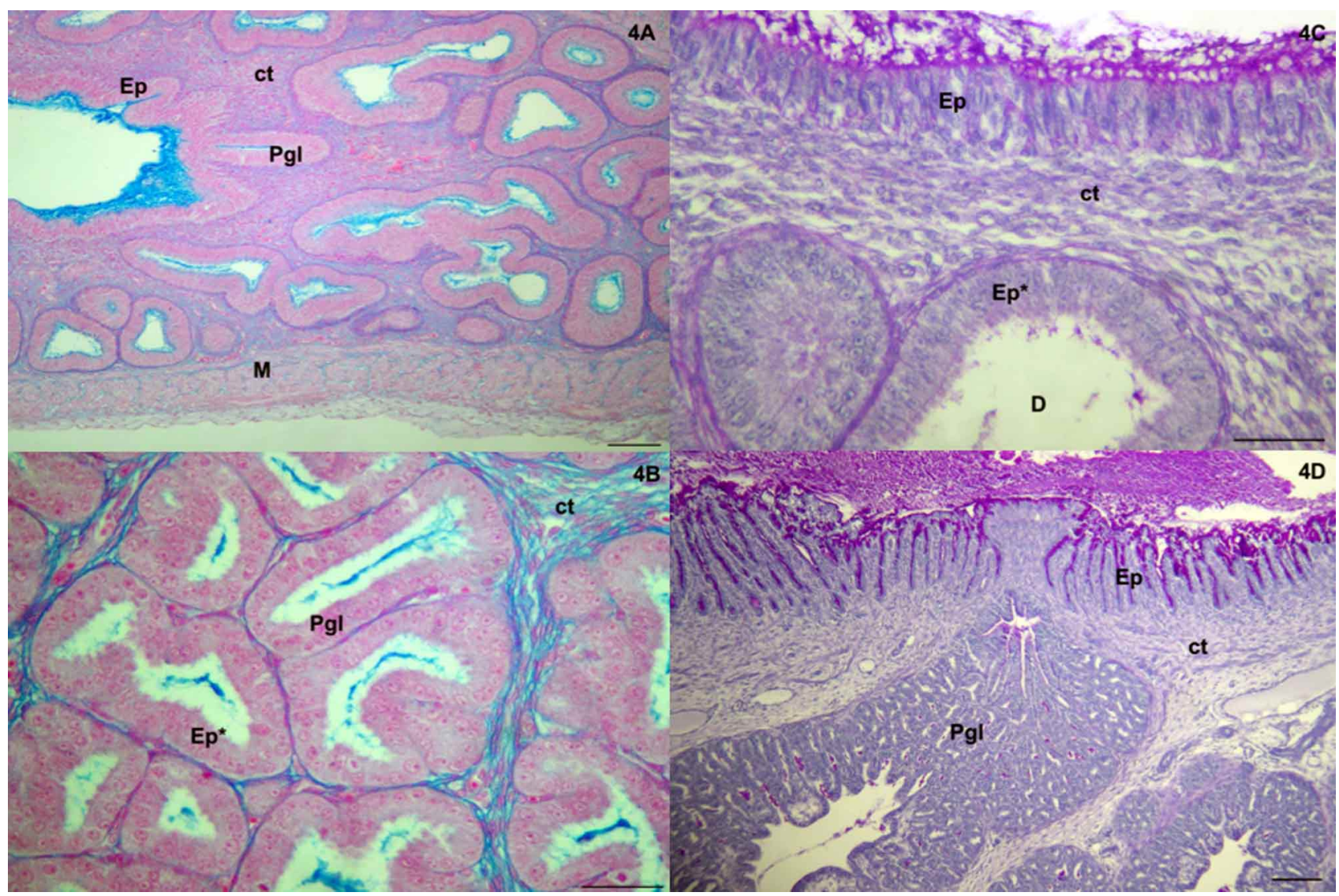

Fig. 4. Histochemical characteristics of proventriculus at different development stages. The superficial epithelium showed reative in all stages from the 12th day (A) to the 20th days (D). Until 20th day (C), proventricularis glands reacted weakly to AB pH 2.5 and PAS. Embryos of 12 days (A) and 15 days (B) stained with AB and 13 days (C) and 19 days (D) with PAS. (Ep) Superficial epithelium; (Ep*) Glandular epithelium; (Pgl) Proventricular gland primordial; (ct) Connective tissue; (D) Excretory duct; (M) Muscle layer. (A) (B) (C) Barr $=50 \mu \mathrm{m}$ e (B) Barr $=100 \mu \mathrm{m}$.

cells were positive for the $\mathrm{AB}$ techniques (Fig. 6A and $\mathrm{C}$ ), whereas in 12-day-old (Fig. 6B) to 20-day-old embryos (stage 28 to 45 ) the gizzard's mucosa were positive for PAS and 13-day-old to 20-day-old for the AB techniques (Fig. $6 \mathrm{~B}, \mathrm{C}$ and $\mathrm{D})$.
From the 13th day on (stages 38 and 39) the surface epithelium started showing irregularities on the apical border. After the 14th day (stages 39), the layer of epithelial cells was taller, as if there was a cellular proliferation and an invasion of those cells in the connective tissue. In this stage, 


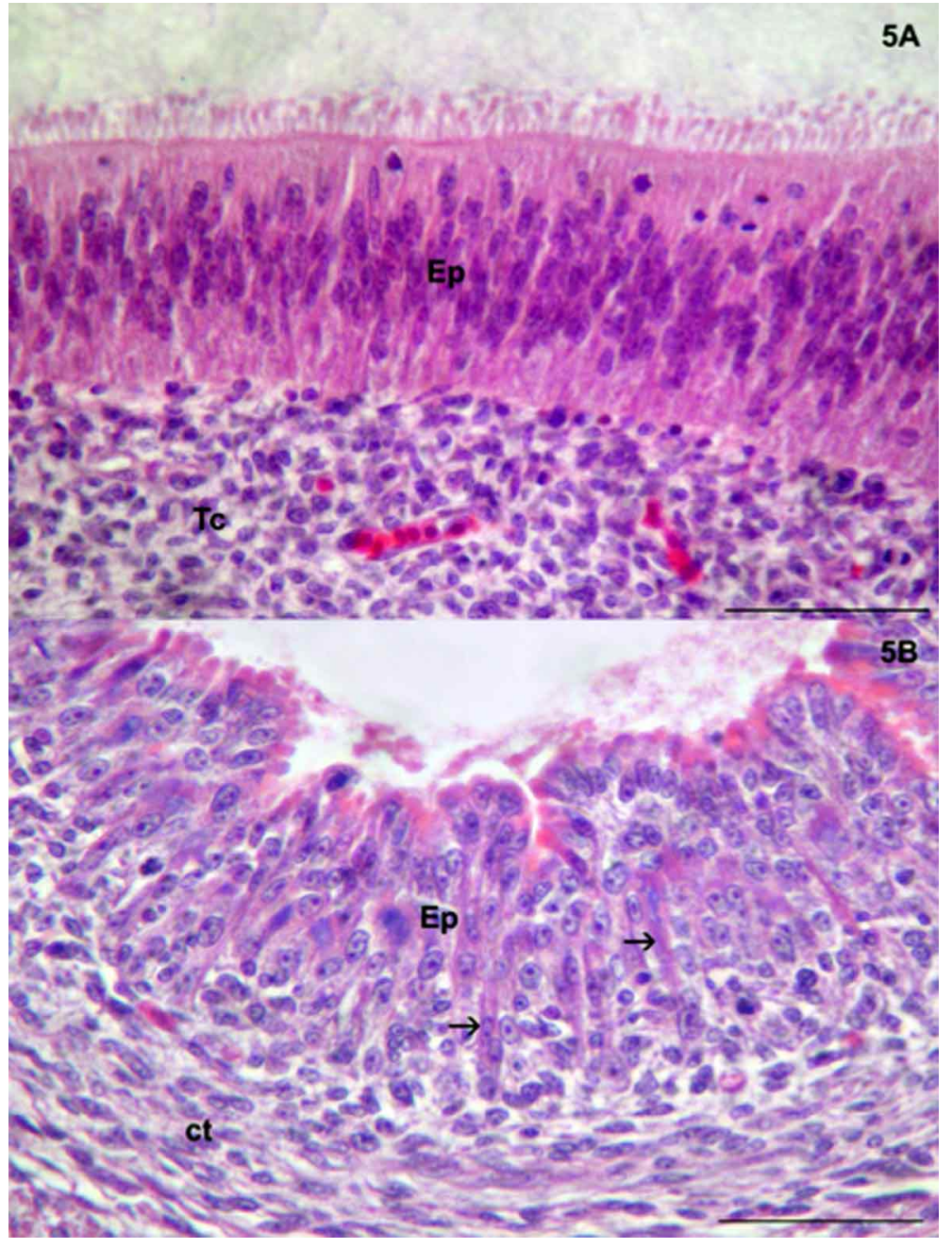

Fig. 5. Histological structure of gizzard at different development stages. Embryos at the 12th days (A) showed pseudostratified epithelium in mucosa layer. The 16 th days (B), the superficial epithelium has been evidenced simple cubic. Since the 17th day, the tubular gland has been considered formed (HE). (Ep) Superficial epithelium; (ct) Connective tissue; (v) Blood vessel; (setas) Intracellular space. (A) Barr $=50 \mu \mathrm{m}$ e (B) Barr $=100 \mu \mathrm{m}$

Table III. Histochemical reactions of GAG's in the gizzard of chick embryos.

\begin{tabular}{lcccc}
\hline Days of & \multicolumn{2}{c}{ PAS } & \multicolumn{2}{c}{ AB 2.5 } \\
\cline { 2 - 5 } Incubation & Lining & Glands & Lining & Glands \\
\hline 12 & ++ & $\sim$ & + & $\sim$ \\
13 & ++ & $\sim$ & + & $\sim$ \\
14 & ++ & $\sim$ & + & $\sim$ \\
15 & +++ & $\sim$ & + & $\sim$ \\
16 & +++ & + & + & + \\
17 & +++ & ++ & ++ & ++ \\
18 & +++ & ++ & ++ & ++ \\
19 & +++ & ++ & ++ & ++ \\
20 & +++ & ++ & ++ & ++
\end{tabular}

$(+++)$ Strong reaction, $(++)$ moderate reaction; $(+)$ weakly reaction, $(-$ ) negative reaction, $(\sim)$ structure is not yet formed the cells showed a slight lack of cohesion, because they were reorganizing themselves, probably to form the tubular glands (Fig. 5B; Fig. 6D). Intercellular spaces or gaps appeared between cells, separating them by the lateral membrane. These intercellular spaces were filled with an acidophilic secretion. The differentiation of the epithelium started at the final third of the gizzard, a portion close to the transition to the small intestine. From the 15 th day on (stage 40), the epithelium of the mucosa differentiated itself and gradually took the shape of a simple epithelium; the cells became cube-like with spherical nucleus and acidophilic cytoplasm. In 15 and 16-day-old embryos, the superficial epithelium were positive for the production of neutral and acid GAG's (Fig. 6D). From the 17th day on, the tubular glands were already formed, since they presented well-defined grooves. At this stage, all regions of the tubular gland were positive for the histochemical techniques. The cells were positive for the $\mathrm{AB}$ and PAS technique with the same intensity in all portions of the gland. There was no formation of a secretion plate until the 20th day of development (Fig. 5B; Fig. 6D).

\section{DISCUSSION}

The gastroesophageal tract is covered by a mucosa that is different in each segment, according to its structure and function. The gastroesophageal mucosa has glands and cells that secrete GAG's; the mucus secreted by these cells and glands forms a protective layer (Díaz et al., 2003; Piel et al., 2005; Kierszenbaum, 2008). The cells that produce neutral GAG's are positive to the PAS technique, whereas the acid GAG's react to the $A B$ technique. In the digestive tract, the neutral GAG's form slightly viscous mucus that favors the digestive transit, lubricating food particles, allowing them to be pushed to the next segment. The acid GAG's have high viscosity, and are very important to trap particles and to form a protective barrier against mechanical friction and the action of the digestive acid (Sibbing \& Uribe, 1985; Kierszenbaum). The composition and dynamics of secretion differ according to the need and function of the epithelial tissues in response to environmental conditions (Díaz et al.; 


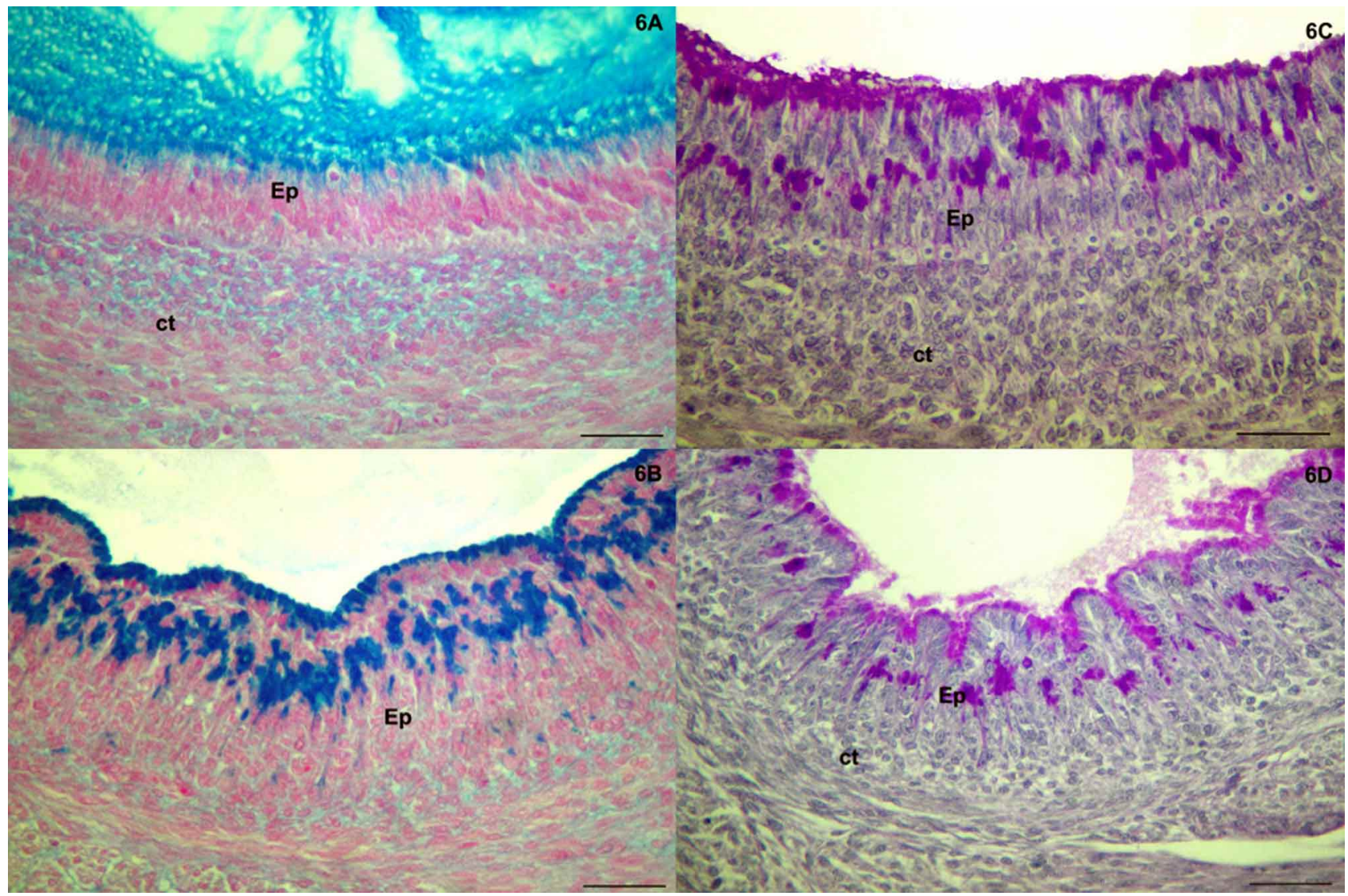

Fig. 6. Histochemical characteristics of gizzard at different development stages. All stages showed reactivity to AB pH 2.5 and PAS. Embryos of 12 days (A), 13 days (B), 12 days (C), 15 days (D) of development. Embryos from the 12th days to the 15th days showed reactive in mucosa. (Ep) Superficial epithelium; (ct) Connective tissue. (M) Muscle layer. Figures (A) Barr= 100 $\mu \mathrm{m}$; (B), (C) e (D) Barr $=50 \mu \mathrm{m}$.

Kierszenbaum). The GAG's can be histochemically classified as neutral or acid.

At the beginning of the development, the mucosa layer of the esophagus has secretory epithelial cells in the apical surface that secrete both neutral and acid GAG's. The secretory activity of these cells is probably meant to compensate the lack of mucosa glands and the little production of GAG's during their formation. However, on the 20th day of development, contrary to what happened on the surface epithelium, the esophageal glands become producers of acid and neutral GAG's, which indicates that at this final stage of development the glands are completely formed and fully functional. Similar results were observed in adults of several bird species.

We monitored the development of the proventriculus from the 12th day on and our histological findings corroborate Toner (1966), Takiguchi et al.; Sgambati et al. (1996) and Aksoy \& Cinar. According to Takiguchi et al., and Aksoy \& Cinar, the proventriculus on the 9th day of embryological development is covered by a pseudostratified cylindrical epithelium that remains until the 14th day. Sgambati et al. (1996) observed the primordium of the proventricular gland around the 7th day, describing it as a small projection within the mesenchyme, but from the 8th day on it was elongated and had a tubular shape. According to Aksoy \& Cinar, the gland in this stage is initially covered by a pseudostratified cylindrical differentiating on simple cylindrical epithelium, which corroborates the description by Torner. This author observed that the epithelial cells become cube-shaped around the 13th day. However, Sgambati et al. (1996) and Aksoy \& Cinar only observed a change in the epithelium that forms the gland on the 15th day.

The histochemical characteristics of the proventriculus corroborate Sgambati et al. (1996), the surface epithelium showed low production of acid and neutral GAG's from the 7th to the 10th day, but the production increased 
progressively from the 11th day of incubation on. The continuous production of neutral and acid GAG's protects the gastric mucosa since the initial stage of development. In the adult animal, the muscularis of the mucosa is formed by a discontinued layer of smooth muscle fibers that are distributed among the proventricular glands, located in the submucosa (Banks). However, staining with Gomori's trichrome showed that the muscularis of the mucosa of the proventriculus is slightly evident in 12 to 20-day-old embryos. Hence, the submucosa cannot be classified as a layer due to the lack of a well-defined structure; so we considered that the proventricular glands were located in the connective tissue of the mucosa-submucosa.

The histological and histochemical characteristics of the gizzard of G. gallus had already been investigated by Pinheiro et al. (1989) and Sgambati et al. (1995). The epithelium of the mucosa was described as pseudostratified cylindrical in 5 to 15-day-old embryos; on the 12th day, the epithelium of the mucosa was taller with projections in the apical membrane. It was observed that on the 15 th day on, the epithelium has already presented a cube-like shape, spherical nucleus, and has been forming the tubular gland (Pinheiro et al.). From the 6th to 12th day, the lining epithelium produced neutral GAG's only in the apical portion, whereas Pinheiro et al. observed a production in the middle and apical portion. Sgambati et al. (1995) and Toner (1966) have described the epithelium from 7 th to the 9 th day, consisting of four to five cellular layers. Sgambati et al. (1995) also observed intercellular spaces from the 14th day of incubation, followed by cellular proliferation on underlying mesenchyme, which originated primordia of tubular glands.

Sgambati et al. $(1995,1996)$ described the difference in the production of GAG's in the proventriculus and gizzard of G. gallus during embryogenesis, and suggested that these changes are related to physiological differences among these organs. The present study also included the esophagus, in which we identified histological and histochemical alterations during the development. We agree that these are adaptive alterations related to the function of the organ and to the stage of embryogenesis.

\section{CONCLUSION}

The morphogenesis of the digestive tract of G. gallus corroborates previous studies. The present study showed that during the development of the esophagus and stomach, the mucosa layer showed production and accumulation of GAG's and the differences in the production of mucus in the three segments of the digestive tract are probably related to different stages of development, and to functions and physiological requirements of each segment in response to the progressive adaptation of the embryo to the post-hatching life.

VENTURA, A.; DO NASCIMENTO, A. A.; DOS SANTOS, M. A. J.; VIEIRA-LOPES, D. A.; SALES, A. \& PINHEIRO, N. L. Descripción histologica de la morfogénesis de la mucosa gastroesofágica de Gallus gallus domesticus (Linnaeus, 1758). Int. J. Morphol., 31(4):1331-1339, 2013.

RESUMEN: La morfogénesis de la mucosa gastroesofágica implica alteraciones morfológicas relacionadas con su estructura y la función de cada segmento. El presente estudio describe la histogénesis del epitelio secretor mucinoso y de las glándulas del esófago, molleja y proventrículo del pollo (G. gallus), ademas de identificar los cambios em el patrón de secreción de glicocosaminoglicanos (GAG's). Se utilizaron treinta y ocho embriones de pollo. El material recogido fue procesado de acuerdo a la rutina histológica y posteriormente las secciones se tiñieron con hematoxilina-eosina para su análisis histológico, con tricrómico de Gomori para identificar el tejido conectivo y las fibras de colágeno y con PAS y AB pH 2,5 para el análisis GAG's neutro y ácido. En una etapa avanzada de desarrollo de los embriones, se pudo obervar en la pared del esófago cuatro capas: mucosa, submucosa, muscular y serosa, mientras que el proventrículo y molleja se muestra constituida por tres capas: mucosa, muscular y serosa. En los tres segmentos de la superficie, el epitelio se identificó como mucinoso y en el esófago sólo en la etapa inicial de desarrollo. Las glándulas del proventrículo se empiezan a formar en las primeras etapas de desarrollo, mientras que en las glándulas tubulares de la molleja comienzan su sólo después del día 15. Las diferencias en la producción de GAG’s en estas regiones del tracto digestivo están relacionadas con las etapas de desarrollo, las funciones y necesidades fisiológicas de cada segmento del cuerpo y se adapta gradualmente a la vida después de la eclosión.

PALABRAS CLAVE: Embriones de pollo; Desarrollo; Glicosaminoglicanos; Esófago; Estómago.

\section{REFERENCES}

Aksoy, A. \& Cinar, K. Distribution and ontogeny of gastrin- and serotonin-immunoreactive cells in the proventriculus of developing chick, Gallus gallus domesticus. J. Vet. Sci., 10(1):9-13, 2009. 
VENTURA, A.; DO NASCIMENTO, A. A.; DOS SANTOS, M. A. J.; VIEIRA-LOPES, D. A.; SALES, A. \& PINHEIRO, N. L. Histological Description of Morphogenesis of the Gastroesophageal Mucosa of Gallus Gallus Domesticus (Linnaeus, 1758). Int. J. Morphol., 31(4):1331-1339, 2013.

Banks, W. J. Histologia Veterinária Aplicada. 2a ed. Rio de Janeiro, Manole, 1992. pp.462-3.

Catroxo, M. H. B.; Lima, M. A. I. \& Cappellaro C. E. M. P. D. M. Histological aspects of the stomach (proventriculus and gizzard) of the red-capped cardinal (Paroaria gularis gularis Linnaeus, 1766). Rev. Chil. Anat., 15(1):19-27, 1997.

Díaz, A. O.; Garcia, A. M.; Devincenti, C. V. \& Goldemberg, A. L. Morphological and Histochemical Characterization of the Mucosa of the Digestive Tract in Engraulis anchoita (Hubbs and Marini, 1935). Anat. Histol. Embryol., 32(6):341-6, 2003.

Fukuda, K. \& Yasugi, S. The molecular mechanisms of stomach development in vertebrates. Dev. Growth Differ., 47(6):375$82,2005$.

Hamburger, V. \& Hamilton, H. L. A series of normal stages in the development of the chick embryo. J. Morph., 195(4):231$72,1992$.

Illanes, J.; Fertilio, B.; Quijada, M.; Leyton, V. \& Verdugo, F. Descripcion histologica de las glandulas anexas del aparato digestivo de Struthio camelus var. domesticus. Int. J. Morphol., 24(3):297-302, 2006.

Kierszenbaum, A. L. Histology and cell biology: an introduction to pathology. 2nd ed. St. Louis, Elsevier, 2008. pp.445-7.

Klasing, K. C. Avian gastrointestinal anatomy and physiology. Sem. Avian Exotic Pet Med., 8(2):42-50, 1999.

Leksrisompong, N.; Romero-Sanchez, H.; Plumstead, P. W.; Brannan, K. E. \& Brake, J. Broiler incubation. 1. Effect of elevated temperature during late incubation on body weight and organs of chicks. Poult. Sci., 86(12):2685-91, 2007.

Liman, N.; Alan, E. \& Kücük Bayram, G. The differences between the localizations of MUC1, MUC5AC, MUC6 and osteopontin in quail proventriculus and gizzard may be a reflection of functional differences of stomach parts. J. Anat., 217(1):57-66, 2010.

Piel, C.; Montagne, L.; Sève, B. \& Lallés, J. P. Increasing digesta viscosity using carboxymethylcellulose in weaned piglets stimulates ileal goblet cell numbers and maturation. J. Nutr., 135(1):86-91, 2005.

Pinheiro N. L.; George L. L. \& Mota, D. L. Histogenesis and histochemistry of the secretion plate: detection of glycans and neutral glycoproteins synthetized by epithelial components of the gizzard mucosa of Gallus gallus. Gegenbaurs Morphol. Jahrb., 135(3):385-95 1989.

Sgambati, E.; Gheri Bryk, S. \& Gheri, G. Histochemical study of the epithelial mucins in the gizzard of the chick embryo. Ital. J. Anat. Embryol., 101(3):173-85, 1996.
Sgambati, E.; Bryk, S. G. \& Gheri, G. Histochemical characterization of the mucins of the epithelial cells in the chick embryo proventriculus. Ital. J. Anat. Embryol., 100(2):83-97, 1995.

Shin, M.; Watanuki, K. \& Yasugi, S. Expression of Fgf10 and Fgf receptors during development of the embryonic chicken stomach. Gene Expr. Patterns, 5(4):511-6, 2005.

Sibbing, F. A. \& Uribe, R. Regional specializations in the oropharyngeal wall and food processing in the carp (Cyprinus Carpio L.). Neth. J. Zool., 35(3):377-422, 1985.

Smith, D. M.; Grasty, R. C.; Theodosiou, N. A; Tabin, C. J. \& Nascone-Yoder, N. M. Evolutionary relationships between the amphibian, avian, and mammalian stomachs. Evol. Dev., 2(6):348-59, 2000.

Takiguchi, K.; Yasugi, S. \& Mizuno, T. Developmental changes in the ability to express embryonic pepsinogen in stomach epithelia of chick embryos. Roux's Arch. Dev. Biol., 197:56$62,1988$.

Toner, P. G. Development of the acid secretary potential in the chick embryo proventriculus. J. Anat., 99:389-98, 1965.

Torner, P. G. Ultrastructure of the developing gizzard epithelium in the chick embryo. Z. Zellforsch. Mikrosk. Anat., 73(2):22033, 1966.

Xu, J.; Delproposto, Z.; Zhou, Z.; Shen, H.; Xuan, S. Y.; Li, Q. H.; Haacke, E. M. \& Hu, J. In ovo monitoring of smooth muscle fiber development in the chick embryo: diffusion tensor imaging with histologic correlation. PloS one, 7(3):e34009, 2012.

Correspondence to:

Adriana Ventura

Postgraduate Program in Animal Biology

Universidade Federal Rural do Rio de Janeiro

Seropédica, 23.890-000

RJ - BRAZIL

Email: ventura-ufrrj@hotmail.com.

Received: 22-02-2013

Accepted: 02-11-2013 